University of South Carolina

Scholar Commons

3-1972

\title{
On the Net Present Value Rule for Educational Investments
}

\author{
Elchanan Cohn \\ University of South Carolina - Columbia, feu00004@moore.sc.edu
}

Follow this and additional works at: https://scholarcommons.sc.edu/econ_facpub

Part of the Finance and Financial Management Commons

\author{
Publication Info \\ Published in Journal of Political Economy, Volume 80, Issue 2, 1972, pages 418-420. \\ http://www.press.uchicago.edu/index.html \\ (C) 1972 by University of Chicago Press
}

This Article is brought to you by the Economics Department at Scholar Commons. It has been accepted for inclusion in Faculty Publications by an authorized administrator of Scholar Commons. For more information, please contact digres@mailbox.sc.edu. 


\title{
On the Net Present Value Rule for Educational Investments
}

\author{
Elchanan Cohn
}

Pennsylvania State University

Hansen (1963), in his study on the profitability of investment in education, has noted that the present value of lifetime income is deficient as an investment criterion because it omits the direct educational costs from the benefit-cost calculations. He also demonstrates that the ranking of educational investments is sensitive to the choice of the discount rate used in calculating the present value estimates. He argues that the internal rate of return corrects the above deficiencies and, therefore, is a superior tool for analysis. Similar arguments in favor of the internal rate of return (IROR) have been voiced by other authors. ${ }^{1}$

Unfortunately, much of the argument against the present value rule is based on false premises. First, it is obviously not the present value of gross lifetime income which should be compared with the IROR; rather, the present value of lifetime income net of costs is the proper rule for comparison. Second, the fact that the net present value may be sensitive to the rate of discount is not a deficiency but, rather, an important asset which ought not to be neglected. Further, when investments are sequentially interdependent or mutually exclusive, as they are in education, the IROR rule will frequently be unreliable.

It has been argued that the net present value rule is not applicable unless and until the "true" and appropriate rate of discount is known. Since there is no agreement on which rate of discount is "proper" for public or private investment decisions, it appears that the net present value rule is highly unsatisfactory in actual applications. The IROR, on the other hand, can be computed without any reference to a discount rate, and thus it appears to be a great deal more useful for application of public or private investment decisions.

This argument, however, can hardly be justified on either theoretical grounds or computational convenience. First, the IROR rule states that the computed internal rate of return should be compared with the chosen discount rate (Prest and Turvey 1965, p. 703). While it is true that one could compute the IROR without having to make a decision on the "proper" discount rate, once a decision on the profitability of the invest-

1 See, for example, Carrol and Ihnen (1967). 
ment is sought - and this is the prime objective of cost-benefit analysisa choice of a discount rate must be made. In other words, the use of the IROR postpones the decision of which rate of discount is "proper" to the time when an investment decision is to be made. Second, the argument that the use of the net present value rule necessitates computation of the net present value for a wide range of discount rates is a very weak argument against the application of the latter, since the utilization of electronic computers (now so widely available) makes such computations a simple matter. Indeed, where the income stream takes other than a mathematically defined form, the computation of the IROR involves iterations entailing computations of a series of present values in any case. Moreover, the knowledge of the sensitivity of the net present value to variations in the rate of discount is of paramount importance to the decision maker (Hirshleifer, DeHaven, and Milliman 1960, pp. 165-66).

In a recent article, Schultz argues that economists are only aware of "Hirshleifer's paper [1958], but unaware of Bailey's classic paper [1959], which shows that Hirshleifer's analysis is not sufficient to solve the multiperiod case in full generality" (Schultz 1967, p. 307). Even if it were true that economists are unaware of Bailey's contribution, ${ }^{2}$ the fact that the net present value rule is not always correct provides no justification for the use of the IROR. This comment is particularly pertinent for investment decisions involving the ranking of investments, in which the IROR can often lead to erroneous results. ${ }^{3}$

It is hoped that this note will stimulate researchers in this area to present information concerning not merely internal rates of return but also net present values for a wide range of discount rates.

\section{References}

Bailey, Martin. "Formal Criteria for Investment Decisions." J.P.E. 67 (October 1959) : 476-88.

Carrol, Adger B., and Ihnen, Loren A. "Costs and Returns for Two Years of Postsecondary Technical Schooling: A Pilot Study." J.P.E. 75 (December 1967) : 862-73.

Eckstein, Otto. "A Survey of the Theory of Public Expenditure Criteria." In Public Finances: Needs, Sources and Utilization, edited by J. M. Buchanan. Princeton, N.J.: Princeton Univ. Press, 1961.

Hansen, W. Lee: "Total and Private Rates of Return to Investment in Schooling." J.P.E. 71 (April 1963) : 128-40.

Hirshleifer, Jack. "On the Theory of Optimal Investment Decision." J.P.E. 66 (August 1958) : 329-52.

2 It is not clear what evidence Schultz has to corroborate this statement. One indication that it may not be true is the fact that the reading list in the capital theory course in my alma mater (Iowa State) included both Bailey's and Hirshleifer's papers.

${ }^{3}$ For authoritative analyses, consult, for example, McKean (1958) and Eckstein (1961). 
Hirshleifer, Jack; DeHaven, James C.; and Milliman, Jerome W. Water Supply -Economics, Technology, and Policy. Chicago: Univ. Chicago Press, 1960.

McKean, Ronald N. Efficiency in Government through Systems Analysis. New York: Wiley, 1958.

Prest, A. R., and Turvey, R. "Cost-Benefit Analysis: A Survey." Econ. J. 75 (December 1965): 683-735.

Schultz, Theodore W. "The Rate of Return in Allocating Investment Resources to Education." J. Human Resources 2 (Summer 1967) : 293-309. 
Copyright of Journal of Political Economy is the property of University of Chicago Press and its content may not be copied or emailed to multiple sites or posted to a listserv without the copyright holder's express written permission. However, users may print, download, or email articles for individual use. 